\title{
CHARACTERISTICS OF MAIZE GROWING FARMERS, VARIETAL USE AND CONSTRAINTS TO INCREASE PRODUCTIVITY IN SELECTED VILLAGES IN THE EASTERN CAPE PROVINCE OF SOUTH AFRICA
}

\author{
Chimonyo, V. G. P. ${ }^{1}$, Mutengwa, C. S. ${ }^{2}$, Chiduza, C. ${ }^{3}$ and Tandzi, L.N. ${ }^{4}$
}

Corresponding author: C.S. Mutengwa. Email: cmutengwa@ufh.ac.za

\begin{abstract}
The need to increase self-sufficiency of rural agricultural systems has been a centre of focus for many extension programs aimed at rural development and improved livelihoods. Numerous biotic, abiotic and socio-economic factors affect maize production for resource poor farmers in the Eastern Cape (EC), which is one of the poorest Provinces in South Africa. Focus group discussions and semi-structured questionnaires were used to identify farmer characteristics, and specific production constraints influencing maize productivity in Jixini and Mkhwezo villages, of O. R. Tambo District in the EC Province. Elderly farmers who are above 56 years dominated the studied farming communities. The predominant varieties used were local landraces (53\%) followed by hybrids (31\%) and improved open pollinated varieties (OPVs) (11\%). Farmers preferred local landraces as they were considered more palatable. Unmarried farmers were the least productive farmer group due to shortages of labour, use of landrace varieties and inadequate fertilizer. The main production constraints faced by farmers, were too much rain, pests and diseases infestation, drought stress due to climate change, and lack of fencing of the out-fields. Increasing the involvement of youths in agricultural activities could improve maize productivity. Maize breeding programs should solicit information on farmerpreferred traits and incorporate them into the improved varieties to enhance their desirability and adoption. Targeting of varieties should be guided by the most common constraints affecting maize productivity in a specific location rather than issuing blanket recommendations. Additionally, agricultural extension programs could improve their service delivery by having good knowledge of target-farmer traits, their farming practices and prevailing constraints. Information in this manuscript can go a long way in improving extension service delivery in the EC Province of the country.
\end{abstract}

Keywords: Maize; Focus Group Discussions; Socio-Economic; Rural Livelihood, Agricultural extension

\section{INTRODUCTION}

\footnotetext{
${ }^{1}$ Post-Doctoral fellow at University of KwaZulu Natal. Centre for Transformative Agriculture and Food System. School of Agriculture, Earth and Environmental Sciences. P/Bag x01, Scottsville, 3209 Pietermaritzburg, South Africa. Email: vimbayc@gmail.com/chimonyov@ukzn.ac.za, ORCID: 0000-0001-9912-9848

2 Associate Professor, Genetics and Plant Breeding. Department of Agronomy, Faculty of Science and Agriculture, P/Bag X1314, Alice, 5700, South Africa. Email: cmutengwa@ufh.ac.za, ORCID: 0000-0002-79685131

${ }^{3}$ Professor, Crop Science in the Department of Agronomy, Faculty of Science and Agriculture, P/Bag X1314, Alice, 5700, South Africa. Email: cchiduza@ufh.ac.za, ORCID: 0000-0001-8237-1937

${ }^{4}$ Post-Doctoral fellow. Department of Agronomy, Faculty of Science and Agriculture, P/Bag X1314, Alice, 5700, South Africa. Email: tnliliane@yahoo.fr, ORCID: 0000-0002-1904-9758
} 
Maize (Zea mays L.) is South Africa's staple crop; it is extensively grown in the Eastern Cape (EC) Province (PROVIDE, 2009; Jacobson, 2013). Coincidentally, the province has one of the highest rates of poverty and food insecurity in South Africa, with more than $65 \%$ of the inhabitants living in rural areas (PROVIDE, 2009). According to Pauw (2006), a considerable number of rural dwellers survive on semi-subsistence agriculture, and are resource-poor. Maize is the main summer crop grown by most of these rural farmers (Sibanda, 2012). However, the majority of farmers are currently unable to produce sufficient grain to meet their household consumption requirements (Bennett, 2002; Jacobson, 2013). Currently, provincial yields range from less than one tonne per hectare for rain-fed maize (Sibanda, 2012) and less than three tonnes per hectare in irrigation schemes (Fanadzo et al., 2009). This is far below the potential and requirements of a rural population of 4.5 million (Statistics South Africa, 2009).

A number of studies have observed several challenges contributing to reduced maize productivity, such as, combined effects of abiotic and biotic stresses, highly variable environmental conditions, use of inappropriate maize varieties and limited resources (Mbuti, 2000; Bennett, 2002; Fanadzo et al., 2009; Jacobson, 2013; Tandzi et al., 2015). Additionally, extension services for smallholder farmers in South Africa have been fraught with challenges such as lack of meaningful contact with farmers, outdated extension methods, low numbers of staff and low aptitudes of extension staff (Ncube 2017). Information on maize productivity in rural EC has largely relied on informal surveys. Due to lack of record keeping by farmers, information gathered is often unreliable in regards to relating performance of maize in farmers' fields to the above-mentioned constraints (Fanadzo et al., 2009).

In light of these constraints, the EC Province has been working towards enhancing maize productivity to improve sustainability of rural livelihoods (Pauw et al., 2006). The Department of Agriculture with the aid of various stakeholders initiated various programmes such as the Massive Food Production Programme (MFPP), which were aimed at promoting cultivation of underutilised out-fields (Jacobson, 2013). This was achieved through providing loans, fertilizer and seed (maize, soybean, millet) packages at subsidized prices (MEDTP, 2010; Matiwana, 2011). However, numerous researchers have noted several problems with these programs. These include delays in input deliveries, lack of extension services, theft in the fields, drought and, in some instances, floods as well as inadequate mechanization affecting timely operations (Fanadzo et al., 2009), high production costs (traction, labour and agro-chemicals), labour shortages and absence of silos (Matiwana, 2011; Jacobson, 2013). Ultimately, these programs have failed to address challenges towards maize productivity. Instead, they have increased farmers' vulnerability to poverty since low yields are still being obtained, which are insufficient to cover production costs, let al.one household requirements (MEDTP, 2010). According to Matiwana, (2011) and Jacobson (2013), these programs were not very successful because they did not consider socio-economic and biophysical factors affecting farmers that were participating.

According to Hoeng et al. (2002), extension services can be more robust when farmers' perceptions and practices are taken into account. An effective extension system should be able to mobilize the social capital of the communities through grouping of farmers with similar circumstances to enable them to either benefit from synergies, or to make it easier for training and sharing of information (Ncube, 2017). Adesehinwa et al. (2004) stated that, understanding socio-economic factors can help in seeking solutions to reduced productivity. Karimuribo et al. (2011) stated that knowledge of production systems and constraints can help in giving reliable production recommendations. Therefore, the objectives of this study were to: (i) 
determine the socio-economic characteristics of maize producing farmers in selected villages of the EC; (ii) understand their farming systems; and, (iii) identify varietal preferences and maize production constraints.

\section{MATERIALS AND METHODS}

\subsection{District selection and characterization}

The study was carried out during the 2009/10 and 2010/11 summer seasons in the O. R. Tambo District Municipality (ORTDM) $\left(33^{\circ} 34^{\prime} \mathrm{S} 28^{\circ} 46^{\prime} \mathrm{E}\right)$ of the EC, South Africa. Xhosa is the main language spoken by the population in that area. The district has an estimated population of 1.7 million, $82.2 \%$ of whom live below the poverty datum line (McCain, 2005). Agriculture is mainly for subsistence, with small-scale farming and open grazed livestock (Musemwa et al., 2008). Mean rainfall in the selected district ranges from 600 to $1800 \mathrm{~mm}$ and is highly dependent on altitude and distance from the Indian Ocean (AGIS, 2011). Agricultural production in the district is mostly rainfed. The altitude ranges from zero to 1650 meters above sea level (masl) (AGIS, 2011), which allows the practice of diverse agricultural enterprises.

\section{Village selection}

Jixini and Mkhwezo villages (Figure 1) were selected based on their contrasting agro-ecologies and consultation with ward extension officers. In Jixini area ( $\left.31^{\circ} 43^{\prime} \mathrm{S} 28^{\circ} 50^{\prime} \mathrm{E}\right)$, there is a moderately high rainfall with an annual precipitation ranging from 800 to $1000 \mathrm{~mm}$ and an average altitude of 643 masl (AGIS, 2011). According to agro-ecological classification, Jixini belongs to a sub-tropical to semi-arid climate and has clay loam black soils. It has a sparsely populated rural settlement, with an approximate area of $5 \mathrm{~km}^{2}$, and an estimated population of approximately 750 inhabitants (Water Service Report Tool, 2011). The second village named Mkhwezo ( $\left.31^{\circ} 42^{\prime} \mathrm{S} 28^{\circ} 30^{\prime} \mathrm{E}\right)$, is located in a lower rainfall area with annual precipitation between 600 and $800 \mathrm{~mm}$, an average altitude of 942 masl (AGIS, 2011). This village has an arid to semi-arid climate, with light brown sandy loam soils. It is approximately $8 \mathrm{~km}^{2}$ and the population is about 1250 inhabitants (Water Service Report Tool, 2011). 
Figure 1: Location of study sites in O. R. Tambo district. Adapted from Mc Cain (2005).

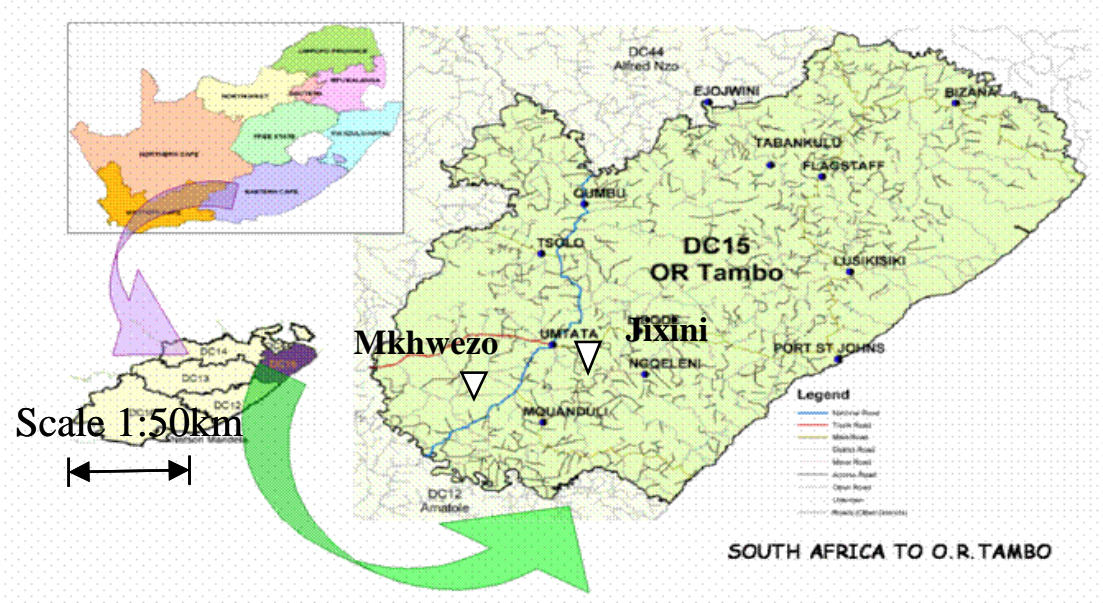

Mkhwezo is, therefore, densely populated (Water Service Report Tool, 2011). Most inhabitants from both villages have home gardens and out-fields. Maize is the main summer crop grown within these fields.

\subsection{Farmer surveys}

To achieve objectives of the study, both informal (focus group discussions (FGD)) and formal (involving distribution of questionnaires) surveys were used and these were conducted during the 2009/10 and 2010/11 seasons, respectively. Xhosa speaking enumerators collected the data. Enumerators were trained before they went into the field for data collection to ensure uniformity in interpretation of the checklist and questionnaire. Qualitative data were collected from 41 participants who attended the FGDs. Before the FGDs, objectives and purpose of the meetings were outlined and explained. During the discussions, a checklist was used to identify farmers' cropping systems, preferred maize traits and maize production constraints. The key informants consisted of at least an experienced farmer (selected by the extension officer) and extension officer, who were interviewed based on the same checklist used in the FGDs.

Key informants and each group of farmers assigned scores to each production constraint and selection criterion. The scores ranged from 1 to $5(1=$ never considered, $2=$ considered but not important, $3=$ moderately important, $4=$ important, and $5=$ very important). To come up with a final rank, production constraints and selection criteria equal to or above 3 were subsequently compared with each other by farmers in a pair-wise fashion.

A semi-structured questionnaire was then designed based on results of the informal surveys with the objective of obtaining detailed information on specific issues and testing hypotheses formulated by researchers after FGDs. The formal surveys were conducted in the same areas where FGDs were held, and involved interviews with 70 individual farmers. The questionnaires were administered to maize growing farmers who were selected with the help of extension workers. The semi-structured questionnaires covered household demographic characteristics 
(age, gender, and marital status, source of income, education, household size, and household labour size), land characteristics and use, maize cropping systems, maize trait preferences and maize production constraints.

\subsection{Statistical analysis}

Data collected were coded and subjected to analysis of variance using the Statistical Package for Social Sciences (SPSS ${ }^{\circledR}$ ) version 15 (SPSS Inc., Chicago IL). Descriptive statistics (means and percentages) generated provided insights into different socio-economic and biophysical features of households. Farmers were categorized into homogenous groups based on a selected set of criteria. This was because differences in perceptions, socio-economic and biophysical features have previously been observed across gender (Odendo et al., 2001) and marital status (Ndiyo and Urassa, 2002) and this was attributed to the different roles played by gender in agriculture. Therefore, in this study, groups were constructed using gender and marital status.

\section{RESULTS}

\subsection{Socio-economic characteristics of farmers}

Table 1 shows the socio-economic characteristics of farmers who were interviewed. Across both sites, there were more female $(55.5 \%)$ than male $(45.5 \%)$ respondents, and the majority $(65.7 \%)$ of farmers were older than 56 years. Married males, who made up the first group of farmers, constituted 36\% of interviewed farmers (Table 1). Twenty percent of interviewed farmers fell into the second farming group, which consisted of married female farmers. The third group consisted of single male farmers, and these constituted $4 \%$ of farmers who were interviewed. The fourth and fifth groups comprised single (19\%) and widowed (16\%) female farmers, respectively. Divorced male and female farmers and widowed male farmers consisted of the least percentage of respondents, which were $1 \%$, each. Therefore, results of these groups were not presented since sample size was too small.

Table 1: Demographic characteristics of farmers interviewed in Jixini and Mkhwezo

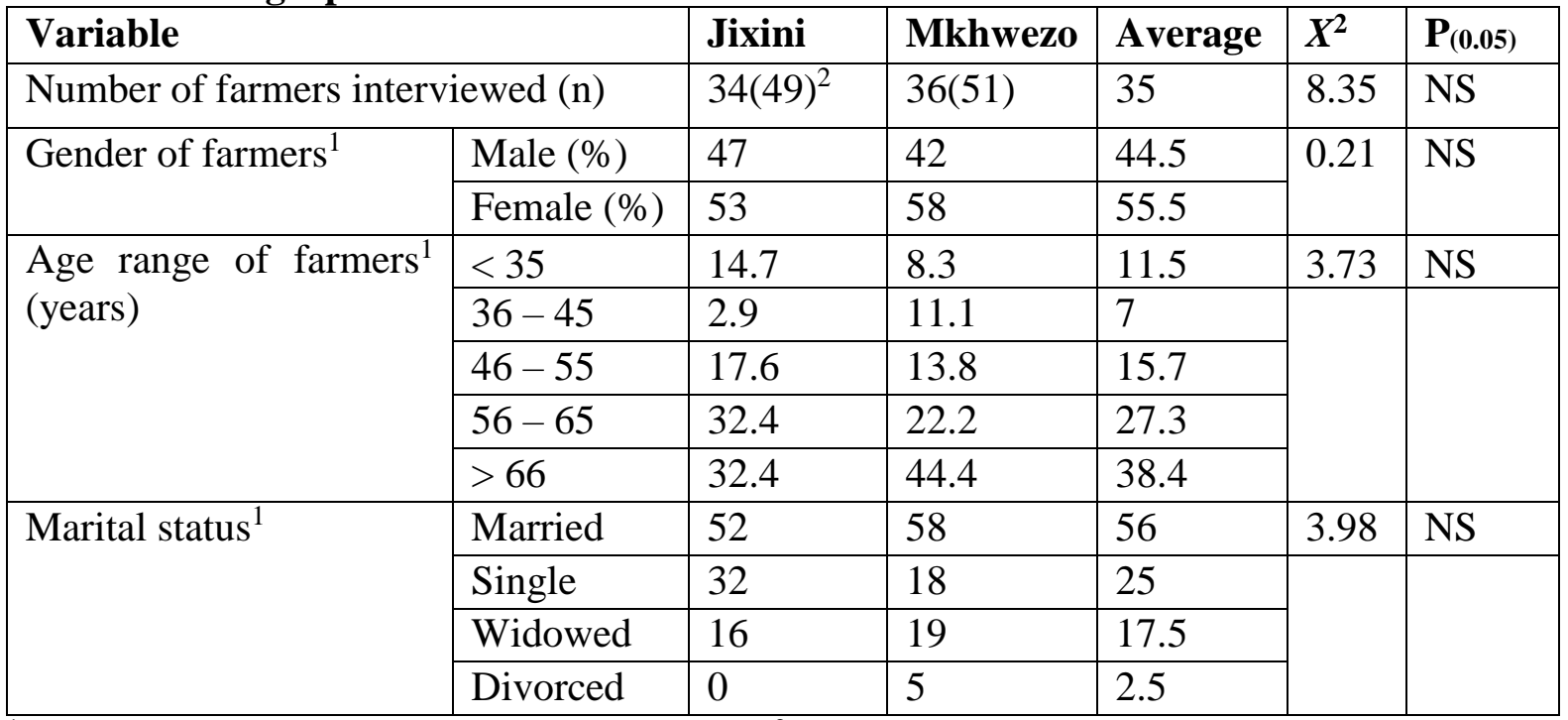

${ }^{1}$ Percentage of respondents in each category; ${ }^{2}$ Number in parenthesis indicates percentage of interviewed farmers. 
Widowed females were the oldest (66 years) farmers followed by married male farmers (59 years old). The youngest group (42 years) of farmers was that of single males. Single male and female farmers had the most years in school (10 years, ) as compared to the other farmer groups (Table 2). Married male and female farmers had the widest range of years in school $(0-12$ years), which gave an average of 7 years for male and 6 years for female married farmers. A household member was defined as an individual sharing an evening meal with the respondents. Married farmers had the largest household sizes of 8 family members for male, and 7 for the female group. Available household labour was defined as individuals actively involved in agricultural activities. Fifty nine percent of family members living with married male farmers, and $55 \%$ of those living with married female farmers were active participants in agricultural production (Table 2). Household sizes for single female farmers and widowed female farmers were somewhat similar, with 6 family members, respectively. However, $65 \%$ of household members residing with widowed female farmers and $51 \%$ living with single female farmers were active in agriculture. Single male farmers had the smallest household size of 4.5, and even had a smaller percentage (31\%) of family members who were actively involved in agriculture. Married male farmers had the most livestock units $(6 \mathrm{LU})$, while single female farmers had the least (2 LU) (Table 2).

Table 2: Selected demographic characteristics and livestock units possessed by different farmer groups

\begin{tabular}{|c|c|c|c|c|c|}
\hline \multirow[b]{2}{*}{ Variable } & \multicolumn{5}{|c|}{ Farmer category } \\
\hline & $\begin{array}{l}\text { Married } \\
\text { male (36) }\end{array}$ & $\begin{array}{l}\text { Married } \\
\text { female (22) }\end{array}$ & $\begin{array}{l}\text { Single } \\
\text { Male (4) }\end{array}$ & $\begin{array}{l}\text { Single } \\
\text { female (19) }\end{array}$ & $\begin{array}{l}\text { Widowed } \\
\text { female (16) }\end{array}$ \\
\hline Age $^{2}$ & $59(47-63)$ & $46(37-53)$ & $42(32-45)$ & $49(46-55)$ & $66(58-72)$ \\
\hline Years $i$ & 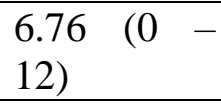 & $\begin{array}{ll}5.92 & (0- \\
12) & \\
\end{array}$ & $\begin{array}{l}10.25(6- \\
12)\end{array}$ & 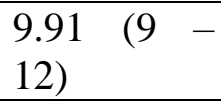 & $\begin{array}{lll}7.45 & (5 & - \\
10) & & \\
\end{array}$ \\
\hline ld size & $\begin{array}{lll}7.76 & (4 & - \\
14) & & \end{array}$ & $6.86(1-9)$ & $4.5(1-9)$ & $5.62(1-9)$ & $5.77(2-9)$ \\
\hline $\mathrm{AHL}^{3}(\%)$ & $\begin{array}{l}59(10 \quad- \\
100)\end{array}$ & $55(14-72)$ & $\begin{array}{lll}31 \quad(25 & - \\
37.5) & \\
\end{array}$ & $\begin{array}{l}51 \quad(11 \quad- \\
100)\end{array}$ & $65(30-83)$ \\
\hline Lives & $\begin{array}{lll}6.08 & (0 & - \\
20.9) & & \\
\end{array}$ & $\begin{array}{lll}4.99 & (0 & - \\
12.8) & & \\
\end{array}$ & $\begin{array}{|lll|}3.68 & (0 & - \\
11.2) & & \\
\end{array}$ & $\begin{array}{l}1.62(0.1- \\
5.7)\end{array}$ & $\begin{array}{lll}3.05 & (0 & - \\
6.78) & & \\
\end{array}$ \\
\hline
\end{tabular}

${ }^{1}$ Number in parenthesis indicates percentage of farmers; ${ }^{2}$ Numbers in parenthesis indicates range; ${ }^{3} \mathrm{AHL}$-Available household labour.

\subsection{Land characteristics and use by farmers}

All the respondents possessed and cultivated home gardens (Table 3). Ownership of out-fields was based on three different types of tenure; (i) possession of title deeds and Lease agreements, (ii) inheritance, and (iii) communal holding, land allocated by chief and/or project manager. The majority of respondents (45.8\%) inherited their out-fields (Table 3). An accumulative percentage of $60.9 \%$ of the farmers were in possession of outfields. Only $44.2 \%$ of these respondents cultivated outfields yearly, while $16.7 \%$ indicated that they no longer cultivated them. Some of the reasons cited by respondents as to why they stopped cultivating outfields were that out-fields lacked fencing to keep stray animals out, were located far from the homesteads and, had been repossessed by the chief and/or project. Other farmers said that they no longer lived permanently at homesteads and/or had become too old. Over-all, respondents without-fields less than 0.5 ha constituted $7.8 \%$, while those in possession of out-fields ranging 
between $0.6-2$ ha were $73.5 \%$. Significant differences $(p<0.05)$ were observed between the villages for respondents having out-fields bigger than 2 ha and these were $30.5 \%$ in Jixini, compared with 7\% in Mkhwezo (Table 3).

Table 3: Land characteristics and tenure for interviewed farmers from Jixini and Mkhwezo

\begin{tabular}{|l|l|l|l|l|}
\hline Variable & \multicolumn{1}{|l|}{ Jixini (\%) } & Mkhwezo (\%) & Ave. \\
\hline Home gardens (HG) & 100 & 100 & 100 \\
\hline Outfields (OF) & Own and cultivates yearly & 44.4 & 44.4 & 44.2 \\
\hline & Own but does not cultivate & 12 & 21.4 & 16.7 \\
\hline & Used to own and cultivate & 15 & 6.2 & 10.6 \\
\hline & Never owned & 29 & 28 & 28.5 \\
\hline \multicolumn{4}{|l|}{} \\
\hline Manner of land acquisition & 29 & 17.5 & 23.5 \\
\hline & Purchase & 45 & 46.5 & 45.8 \\
\hline & Inherited & 10 & 14 & 12 \\
\hline & Allocated by chief & 16 & 21 & 19.5 \\
\hline & Allocated by project manager & \multicolumn{3}{|l|}{} \\
\hline Outfield size & 4.5 & 11 & 7.8 \\
\hline & $<0.5$ ha & 65 & 82 & 73.5 \\
\hline & $0.6-2$ ha & 30.5 & 7 & $18.8^{*}$ \\
\hline
\end{tabular}

The study established that most of the land preparation (58.4\%) was conducted using tractors, which farmers hired from other farmers living within the same village (Table 4). On average, there were two tractors per village. Across both villages, $24.3 \%$ of these farmers indicated that they augmented the use of tractors with animal draught power when ploughing their lands. Results from the investigations also revealed that an average of $11.5 \%$ and $6 \%$ of farmers from both villages only used animal draught and hand hoes to till their lands respectively. Farmers using hand hoes and picks were significantly lower $(\mathrm{p}<0.05)$ in Mkwezo when compared to Jixini (Table 4). Significant differences $(p<0.05)$ were observed between the villages with respect to use of basal fertilizers and farm manure in home gardens (HGs), as well as for use of farm manure in HGs and out-fields (OFs) (Table 4). More farmers in Mkhwezo (91\%) used basal fertilizers in their home gardens compared with Jixini (50\%). However, the scenario was reversed for farm manure use, with $67 \%$ of farmers in Jixini and 31\% in Mkhwezo using farm manure in home gardens. None of the interviewed farmers applied farm manure in their outfields in Mkhwezo, while 36.67\% of farmers applied it in Jixini. On average, 34\% and 32\% of interviewed farmers applied either Urea, LAN or CAN in home gardens and out-fields, respectively, while $38.5 \%$ applied basal fertilizers in their out-fields. The predominant agrochemicals used by $61.4 \%$ of farmers who were interviewed were insecticides. Herbicides were only used in Mkhwezo by $10 \%$ of farmers who were interviewed (Table 4). 
Table 4: Implements used for land preparation, as well as use of fertilizer and agrochemicals by interviewed farmers in Jixini and Mkhwezo

\begin{tabular}{|c|c|c|c|}
\hline Variable & \multicolumn{2}{|c|}{ Jixini (\%) } & $0(\%)$ \\
\hline \multicolumn{4}{|l|}{ Land preparation } \\
\hline Tractor $(\mathrm{Tr})$ & 52.9 & 63.8 & 58.4 \\
\hline Animal draught (Ad) & 11.8 & 11.1 & 11.5 \\
\hline Both Tr and Ad & 23.5 & 25 & 24.3 \\
\hline Hand hoes and picks & 11.8 & 0.1 & 6 \\
\hline \multicolumn{4}{|l|}{ Use of fertilizers (HG) ${ }^{1}$} \\
\hline Basal fertilizer $(2: 3: 2 / 2: 3: 4)$ & 50 & 91 & $70.5^{*}$ \\
\hline Top dressing (urea/LAN/CAN) & 24 & 44 & 34.0 \\
\hline Farm manure & 67 & 31 & $49.0^{*}$ \\
\hline \multicolumn{4}{|l|}{ Use of fertilizers $(\mathrm{OF})^{2}$} \\
\hline Basal fertilizer $(2: 3: 2 / 2: 3: 4)$ & 43.2 & 36.8 & 38.5 \\
\hline Top dressing (urea/LAN/CAN) & 28.7 & 34.5 & 32.1 \\
\hline Farm manure & 36.67 & 0 & $18.4^{*}$ \\
\hline \multicolumn{4}{|l|}{ Agro-chemicals } \\
\hline Insecticides & 61.8 & 61 & 61.4 \\
\hline Herbicides & 0 & 10 & 5 \\
\hline
\end{tabular}

*Significant difference between villages at $\mathrm{p}<0.05$; LAN - Lime ammonium nitrate; CAN Calcium ammonium nitrate; ${ }^{1} \mathrm{HG}$ - Home gardens; ${ }^{2} \mathrm{OF}$ - out fields.

More widowed female farmers $(73 \%)$ cultivated out-fields, and this was followed by $60 \%$ of married male farmers and $57 \%$ of married female farmers (Table 5). The percentage of single farmers cultivating out-fields was slightly lower than the other groups, with 50\% male and 54\% females. Married male and single female farmers cultivated larger out-fields of 1.72 ha and 1.65 ha, respectively, while married female farmers had the least (1.05 ha) (Table 5). The highest yields $(0.68 \mathrm{t} / \mathrm{ha})$ were obtained by married male and widowed female farmers. The lowest yields $(0.11 \mathrm{t} / \mathrm{ha}$ ) were obtained by single female farmers (Table 5$)$. The predominant tool for land preparation by female farmers was tractors, while male farmers supplemented with animal draught and hand held hoes.

Table 5: Land characteristics, method of land preparation and yields obtained for different farmer groups

\begin{tabular}{|l|l|l|l|l|l|}
\hline \multirow{2}{*}{ Variable } & \multicolumn{5}{l}{ Farmer categories } \\
\cline { 2 - 6 } & $\begin{array}{l}\text { Married } \\
\text { male }\end{array}$ & $\begin{array}{l}\text { Married } \\
\text { female }\end{array}$ & $\begin{array}{l}\text { Single } \\
\text { male }\end{array}$ & $\begin{array}{l}\text { Single } \\
\text { female }\end{array}$ & $\begin{array}{l}\text { Widowed } \\
\text { female }\end{array}$ \\
\hline Cultivate outfield (\%) & 60 & 57 & 50 & 54 & 73 \\
\hline $\begin{array}{l}\text { Area under maize } \\
(\text { ha })^{2}\end{array}$ & $\begin{array}{l}1.72(1- \\
7)\end{array}$ & $\begin{array}{l}1.05(0.5- \\
2)\end{array}$ & $1.5(1-2)$ & $1.65(1-3)$ & $1.25(1-2)$ \\
\hline Land preparation & Tr and Da & $\operatorname{Tr}$ & $\operatorname{Tr}$ and Hn & $\operatorname{Tr}$ & $\operatorname{Tr}$ \\
\hline Yield (t/ha $)^{2}$ & $0.68(0.1-$ & $0.53(0.2-$ & $\begin{array}{l}0.4(0.3- \\
1.8)\end{array}$ & $\begin{array}{l}0.11(0.1- \\
1.2)\end{array}$ & $\begin{array}{l}0.68(0.1- \\
2.5)\end{array}$ \\
\hline
\end{tabular}

$\mathrm{Tr}$ - Tractor, $\mathrm{Da}$ - draught animal, $\mathrm{Hn}$ - hand hoes; ${ }^{2}$ Numbers in parenthesis indicate range.

The majority of married male farmers used basal fertilizer in combination with top dressing fertilizer (40\%) and with farm manure (30\%) (Table 6). Five percent of these farmers used only 
top dressing fertilizer, while $25 \%$ of them applied only animal manure in their outfields. Fourteen percent, each, of married female farmers used animal manure and a combination of basal and top dressing fertilizer. A larger percentage (21\%) of married female farmers used animal manure in combination with basal fertilizer. Fifty percent of single male farmers used a combination of basal and top dressing fertilizer, while $50 \%$ of these farmers used only animal manure. Seven percent of single female farmers used only basal fertilizers, while another $7 \%$ used both basal and top dressing fertilizers. The latter fertilizer combination was also used by $33 \%$ of widowed female farmers (Table 6).

Table 6: Percentage of farmers using different types and combinations of fertilizers in home gardens and out fields

\begin{tabular}{|l|l|l|l|l|l|}
\hline \multicolumn{5}{|l|}{ Farmer category } \\
\hline Fertilizer type & $\begin{array}{l}\text { Married } \\
\text { male }\end{array}$ & $\begin{array}{l}\text { Married } \\
\text { female }\end{array}$ & $\begin{array}{l}\text { Single } \\
\text { male }\end{array}$ & $\begin{array}{l}\text { Single } \\
\text { female }\end{array}$ & $\begin{array}{l}\text { Widowed } \\
\text { female }\end{array}$ \\
\hline Basal fertiliser (BF) & 0 & 0 & 0 & 7 & 0 \\
\hline Top dressing fertilisers (TD) & 5 & 0 & 0 & 0 & 0 \\
\hline Manure (M) & 25 & 14 & 50 & 0 & 0 \\
\hline BF and TD & 40 & 14 & 50 & 7 & 33 \\
\hline BF and M & 30 & 21 & 0 & 0 & 0 \\
\hline
\end{tabular}

\subsection{Cropping systems}

All the respondents in Jixini and 95\% in Mkhwezo cultivated maize in their home gardens. An average of $45.5 \%$ of respondents indicated that they practised intercropping with pumpkin, beans or both, while $54.5 \%$ did not see the need to intercrop. Respondents cultivating out-fields only grew maize. Therefore, maize was the most important crop based on frequency of farmers producing it. Other crops grown in both villages included cabbage, spinach, potatoes, pumpkins and carrots.

\subsection{Maize varieties grown by farmers}

There were no significant differences in type of varieties used by farmers in the villages. The predominant varieties used were local landraces $(53 \%)$ followed by hybrids $(31 \%)$ and improved OPVs (11\%). Five percent of the farmers used recycled hybrid seed (Figure 2). 


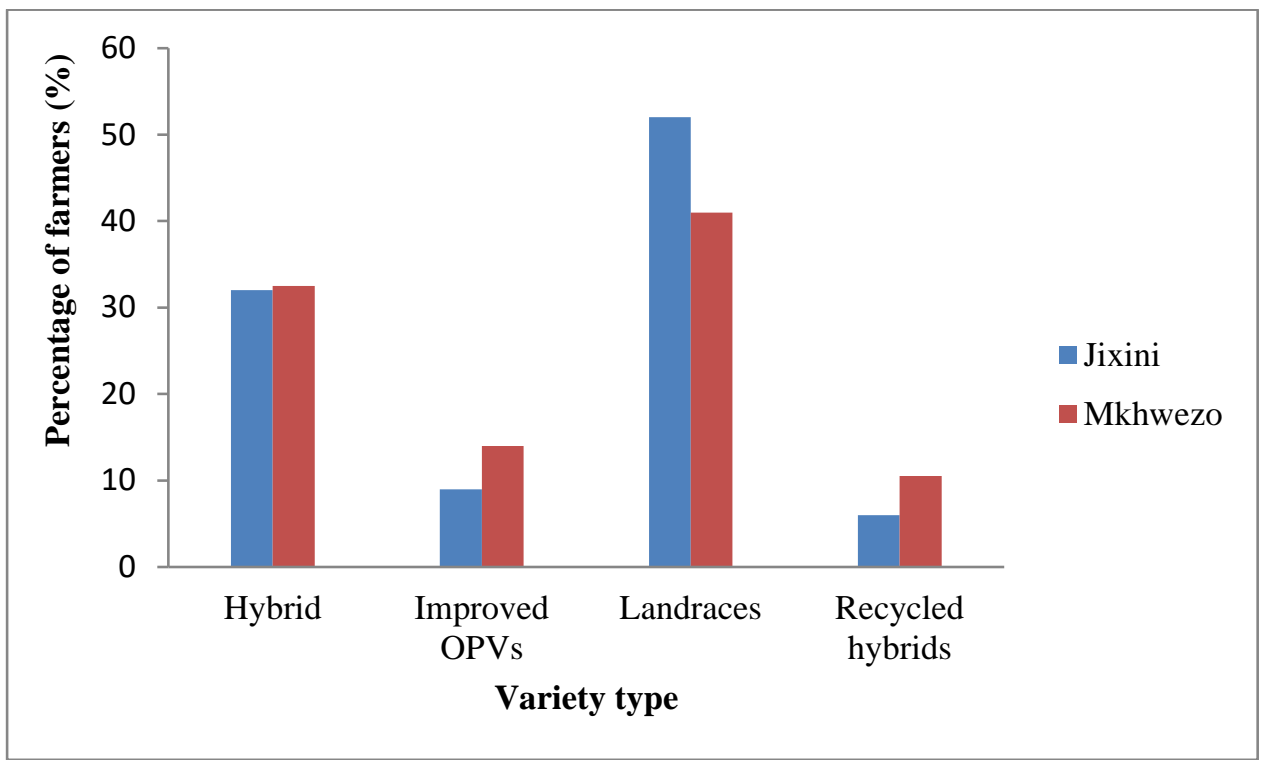

Figure 2: percentage of farmers growing different types of maize varieties in Jixini and Mkhwezo.

Seventy-four percent of male married farmers used hybrid seed, while $16 \%$ and $10 \%$ used OPVs and local landraces, respectively, in their out-fields (Table 7). Seventy-two percent of single and $75 \%$ of widowed female farmers used hybrid seed, while a lesser proportion of the other female farmers used either OPVs or landrace varieties (Table 7).

Table 7: Types maize varieties grown in outfields for the different groups of farmers (\%)

\begin{tabular}{|c|c|c|c|c|c|}
\hline \multirow[b]{2}{*}{ Type of variety } & \multicolumn{5}{|c|}{ Farmer category } \\
\hline & $\begin{array}{l}\text { Married } \\
\text { male }\end{array}$ & $\begin{array}{l}\text { Married } \\
\text { female }\end{array}$ & $\begin{array}{l}\text { Single } \\
\text { Male }\end{array}$ & $\begin{array}{l}\text { Single } \\
\text { female }\end{array}$ & $\begin{array}{l}\text { Widowe } \\
\text { d female }\end{array}$ \\
\hline Hybrid seed $^{1}$ & 74 & 100 & 100 & 72 & 75 \\
\hline Open pollinated varieties & 16 & 0 & 0 & 14 & 17 \\
\hline Local landrace & 10 & 0 & 0 & 14 & 8 \\
\hline Knowing variety name & 10 & 4 & 0 & 0 & 0 \\
\hline
\end{tabular}

${ }^{1}$ Percentage of farmers within each group.

Most married male farmers (50\%) used hybrid seed in their home gardens, while fewer farmers in this group used local landrace varieties (36\%) and OPVs (14\%). On the other hand, $84 \%$ of married female farmers used local landraces, while hybrid or OPVs were used by $8 \%$ each, of these farmers (Table 8). Ten percent and $7 \%$ of male and female married farmers, respectively, were aware of the names of varieties that they were using. The majority of single female farmers $(83 \%)$ used local landrace, while a smaller proportion (17\%) used hybrids in their home gardens. However, more widowed female farmers used recycled hybrid seed, followed by hybrid seed, OPV and local landrace varieties. A small proportion of married (both, male and female) and single male farmers were aware of the varieties they were using (Table 8). 
Table 8: Types maize varieties grown in home gardens for the different groups of farmers $(\%)$

\begin{tabular}{|l|l|l|l|l|l|}
\hline \multirow{2}{*}{ Variety type } & \multicolumn{5}{|c|}{ Farmer category } \\
\cline { 2 - 6 } & $\begin{array}{l}\text { Married } \\
\text { male }\end{array}$ & $\begin{array}{l}\text { Married } \\
\text { female }\end{array}$ & $\begin{array}{l}\text { Single } \\
\text { Male }\end{array}$ & $\begin{array}{l}\text { Single } \\
\text { female }\end{array}$ & $\begin{array}{l}\text { Widowed } \\
\text { female }\end{array}$ \\
\hline Hybrid seed $^{1}$ & 50 & 8 & 50 & 17 & 28 \\
\hline Open pollinated varieties & 14 & 8 & 0 & 0 & 18 \\
\hline Local landrace & 36 & 84 & 50 & 83 & 18 \\
\hline Recycled hybrid & 0 & 0 & 0 & 0 & 36 \\
\hline Knowing variety name & 10 & 7 & 2 & 0 & 0 \\
\hline
\end{tabular}

${ }^{1}$ Percentage of farmers within each group.

An accumulative percentage of $91 \%$ of the farmers obtained yields less than $1 \mathrm{t} / \mathrm{ha}$, whereas yields above $1.6 \mathrm{t} / \mathrm{ha}$ were obtained by only $3 \%$ of the interviewed farmers. Farmers growing hybrid seed followed by improved OPVs obtained the highest yields, while farmers growing landraces and recycled hybrids obtained lower yields (Table 9). Farmers growing local landrace varieties indicated that seed of these varieties were cheaper, grain was more palatable, had a high kernel row number, were nutritious, retainable and adapted to their environment. However, farmers growing hybrids and improved OPVs indicated that these varieties produce high yields and are more marketable than local landraces.

Table 9: Interaction of yield (t/ha) attained and variety type used by interviewed farmers (\%) from Jixini and Mkhwezo.

\begin{tabular}{|l|l|l|l|l|l|}
\hline \multirow{2}{*}{ Variety type } & \multicolumn{4}{|c|}{ Yield (t/ha) } & \multirow{2}{*}{ Total\% of farmers } \\
\cline { 2 - 6 } & $\mathbf{0 . 1 - 0 . 5}$ & $\mathbf{0 . 5 1 - 1 . 0}$ & $\mathbf{1 . 1 - 1 . 6}$ & $\mathbf{1 . 6 1 - 2 . 4}$ & \\
\hline Hybrid & 20 & 7 & 3 & 3 & 33 \\
\hline Improved OPVs & 2 & 6 & 3 & 0 & 11 \\
\hline Local landraces & 40 & 6 & 0 & 0 & 46 \\
\hline Retained hybrid seed & 8 & 0 & 0 & 0 & 8 \\
\hline Total & 42 & 19 & 7 & 3 & 70 \\
\hline Accumulative\% of farmers & 72 & 91 & 98 & 100 & \\
\hline
\end{tabular}

\subsection{Farmers' production constraints}

Constraints faced by farmers during maize production in both villages were significantly different $(p<0.001)$ from each other according to Bartlett's chi-squared test for homogeneity of variance (Table 10). Similar to selection criteria, the overall importance of a constraint was computed based on the accumulative frequency of farmers mentioning it as being important. Overall, too much rain was ranked first, with $36.1 \%$ of the respondents mentioning it as a constraint (Table 10). Occurrence of pests and diseases (30.07\%), drought (28.8\%), climate change (17.04\%) and lack of fencing (15.36\%) were ranked second, third, fourth and fifth, respectively. In Jixini, too much rain (50\%) was ranked first, followed by the occurrence of drought $(32.4 \%)$. A high incidence of pests and diseases $(26.8 \%)$ was ranked third, while attacks by birds, high fertilizer prices, climate change and weed infestation were all tied at fourth position (11.8\%, each) (Table 10). In Mkhwezo, a high incidence of pests and diseases $(33.3 \%)$ was ranked first. Lack of fencing $(27.8 \%)$ and occurrence of drought $(25.2 \%)$ were ranked second and third, respectively. Too much rain and climate change was each ranked 
fourth (22.2\% each) (Table 10). In contrast to the informal survey, FGD revealed that important constraints affecting both villages, in terms of the most to the least important, were lack of tillage equipment, high fertilizer prices, and high herbicide and insecticide prices.

Table 10: Farmers perceptions and ranking of constraints to maize production

\begin{tabular}{|l|l|l|l|}
\hline Source & Jixini & Mkhwezo & Mean \\
\hline Too much rain & $50.0(1)^{1}$ & $22.2(4)$ & $36.1(1)$ \\
\hline Storage facilities & 8.8 & 11 & 9.95 \\
\hline Birds & $11.8(4)$ & 8.3 & 10.05 \\
\hline Pests and diseases & $26.8(3)$ & $33.3(1)$ & $30.07(2)$ \\
\hline Drought & $32.4(2)$ & $25.2(3)$ & $28.8(3)$ \\
\hline High fertilizer price & $11.8(4)$ & 8.3 & 10.07 \\
\hline Unavailable tractor & 5.8 & 5.6 & 5.7 \\
\hline High tractor fees & 0 & 11.1 & 5.55 \\
\hline High seed prices & 5.8 & 11.1 & 8.45 \\
\hline High chemical prices & 0 & 8.3 & 4.15 \\
\hline Inadequate land & 5.8 & 0 & 2.9 \\
\hline Undesirable varieties & 2.9 & 0 & 1.45 \\
\hline Cob rots & 8.95 & 2.7 & 5.82 \\
\hline Climate change & $11.8(4)$ & $22.2(4)$ & $17.04(4)$ \\
\hline Lack of fencing & 2.9 & $27.8(2)$ & $15.36(5)$ \\
\hline Untimely operation & 5.8 & 5.6 & 5.7 \\
\hline Weed infestations & $11.8(4)$ & 2.7 & 7.27 \\
\hline Labour shortages & 0 & 8.3 & 4.15 \\
\hline Low credit access & 2.9 & 16.7 & 9.82 \\
\hline Strong winds & 5.8 & 0 & 2.9 \\
\hline Poor production skills & 2.9 & 2.7 & 2.8 \\
\hline 1 N & & & \\
\hline
\end{tabular}

${ }^{1}$ Number in parenthesis represents overall rank position of constraint in each site; Bartlett's $X^{2}$ $=79.3$, Degrees of Freedom $(n-1)=14 \mathrm{P}=0.001$.

\section{DISCUSSION}

The need to increase self-sufficiency of rural agricultural systems has been a centre of focus for many programs aimed at rural development and improved livelihoods. Methods of intervention have evolved throughout the decades from 'green revolutionary' strategies to more consumer orientated approaches tailor made for improvement of rural livelihoods. Results from the study of socio-economic characteristics and production constraints can thus be used to formulate and recommend reliable and sustainable technologies for rural development and improved livelihoods.

The observation that the majority of farmers interviewed were old (above 56 years, which is near the retirement age of 60 years in South Africa), and could be regarded as inactive to pursue economic activities could be due to the lack of involvement of younger generations in maize production. These findings are consistent with those obtained by Musemwa et al. (2008) who reported that aging farmers dominate the EC Province's agricultural sector. Also, Mngqawa et $a l$. (2016) reported that farmers in Limpopo province were ten years older ( \pm 61.5 years) than those in Mpumalanga ( \pm 51.1 years). Age has a negative impact on the achievement of 
sustainable agriculture for smallholder farmers (Odoemenem and Adebisi, 2011). Young farmers are reported to be more responsive to new ideas and practices, while older farmers are more conservative, and less responsive to the adoption of new ideas and practices (Amaza et $a l .$, 2007). The government and interested stakeholders should, therefore, encourage the participation of youths in agricultural activities as they are the new generation of farmers.

Although farmers were generally old, they were moderately educated having attained at least primary level education. According to Alam (2010), education enables farmers to appreciate the advantages of new technologies. Low levels of farmers' education were reported in several studies as a limiting factor resulting in inability to interpret market information to be used in production planning and marketing in South Africa (Celliers, 2016; Mngqawa et al., 2016). In this regard, these aging farmers could adopt new technologies with little resistance. On the other hand, the observed findings that single farmers, who were also the youngest group, had the most years in school was consistent to observation by Mapiye et al. (2009). These results could be explained in terms of the improved access to education since end of the apartheid era in 1994. Therefore, youths' increased access to formal education will likely make these communities more productive, and more amenable to accept, initiate, and manage development projects as opposed to the less economically active groups.

It was established that farmers used two maize based cropping systems, which were intercropping and mono-cropping. These findings agree with the cropping systems described by Bryndum et al. (2007) for farmers in Pepela village in the ORTDM. It was observed that, within these cropping systems, farmers obtained low maize yields in both outfields and home gardens. These results are also consistent with several reports on maize productivity in the EC Province (MEDTP, 2010). The observed low yields in outfields could be due to farmers using inadequate amounts of fertilizers for hybrid varieties, which require high input levels for them to achieve their yield potential. Furthermore, some farmers were using landraces that are known to succumb to contamination from neighbouring maize field, which could result in them losing their yielding ability (Pixley and Banziger, 2001). An increase in the involvement of household members in agricultural activities was associated with an increase in maize productivity across farmer groups. These results could be attributed to the involvement of unemployed economically active household members (Okoye et al., 2008). Therefore, increasing the involvement of young adults in maize production could result in improved productivity.

The low grain yields observed in home gardens could be attributed to the reduction of cob numbers due to respondents harvesting green mealies for household consumption. This suggests that observed yields would have been higher in home gardens than outfields if maize was grown solely for grain. Furthermore, it was observed that more farmers in the study used organic and inorganic fertilizers in home gardens than outfields. Mandiringana et al. (2005) observed high fertility levels in home gardens than outfields. Farmers were inclined at investing more inputs in home gardens due to improved security of crops grown next to the homestead. The use of cheaper seed alternatives like improved stress tolerant OPVs could be more beneficial to majority of farmers (Jacobson, 2013; Fischer et al., 2015) who used lower levels of inputs since OPVs generally exhibit better yield stability in stress prone environments when compared with hybrid varieties. Furthermore, since Banziger et al. (2005) observed that improved OPVs yield better than landrace varieties, yield improvements could create an incentive for farmers to invest more in fertilizers. 
Although farmers were aware of the benefits of using hybrid seed, the majority of them preferred to grow local landrace varieties. These results are consistent with those obtained by Bellon et al. (2003) and Derera et al. (2006), who observed that farmers preferred using local varieties other than high yielding hybrids. According to Abebe et al. (2005), most hybrid varieties grown in rural communities tend to have more undesirable traits than local landrace varieties. Ntare et al. (2007) reported that farmers reject better performing varieties if they do not possess desired traits. This could also explain why farmers indicated many negative attributes for hybrid varieties than local landraces. Maize breeding programs should, therefore, solicit information on farmer-preferred traits and incorporate them into modern varieties (improved OPVs or hybrids) to enhance their desirability and adoption.

It was observed that during the formal survey, most farmers were unable to state names of varieties they were using. It could be postulated that farmers' interactions within FGDs enabled them to brainstorm variety names, while key informants gave the necessary information, to add on to, and validate findings of the informal survey (Rabiee, 2004). Kotey et al. (2017) reported that extension and advisory services played a critical role in facilitating the adoption of improved agricultural practices. However, it might be difficult to recommend improved varieties in situations where the farmers have very limited knowledge of variety names as was observed in this study.

The land tenures observed can be re-categorized to two main land holdings, the formal (title deeds, lease agreements, inherited) and informal (allocated by chief/project leader) land holding systems. These results are similar to those obtained by Cumming (2007), who observed $66.5 \%$ of private land ownership and $29.5 \%$ for communal lands. Although the agricultural activities and other livelihood options are affected by various factors (climatic conditions, markets, infrastructure, and physical conditions). Adams et al. (1999) stated that, the unequal access to land and insecure land tenure have a negative effect on willingness to invest in the land and livelihoods of smallholder farmers. Kepe and Tessaro (2013) reported that in the EC Province, the government agencies had poor understanding of rural people's land use plans and multiple livelihood strategies. Even though results indicated that access to land was fairly good; however, other disincentives caused low productivity in maize.

Constraint analysis gave an insight to factors affecting maize production in the studied villages. In general, observed constraints highlighted by farmers were similar, but differed in their importance. The observed constraints affecting maize production in the study were infrastructural, financial, biotic and abiotic (Fanadzo et al., 2010). Farmers interviewed during the 2010/11 season considered not all the constraints that ranked highly in the FGDs conducted in the 2009/10 season important. During the FGDs, more emphasis was placed on high cost of production operations, while results on farmer interviews emphasized biotic and abiotic stress factors. Manyevere et al. (2014) found that in Nkonkobe Municipality, erratic rainfall and land degradation lead to land abandonment and declining of crop productivity. Focus group discussions revealed that a major constraint was the lack of tillage equipment. Key informants, however, highlighted that the real problem was the few service contractors and the unavailability of tractors in each village. These results agree with Israel et al. (1999) and Bryndum et al. (2007) who observed few tillage contractors in selected villages of the EC. Furthermore, these observations were substantiated by findings from the household survey, where there were two tractors per village, on average. 
Extreme weather conditions were the most important constraints, and according to Rosenzweig et al. (2000), such events are associated with an increase in the prevalence of insect pests and diseases. This could explain why this constraint ranked highly in both villages. Therefore, varieties with tolerance to multiple stresses could be used to minimise risks of yield losses. This becomes very necessary especially when farmers are faced with multiple stresses as shown by the differential weather patterns experienced during the 2009/2010 and 2010/2011 summer seasons, and low levels of input-use. As a result, recommending varieties should be guided by the most common constraints affecting maize productivity in a specific location rather than variety availability.

Though, heavy rains were mentioned in Mkhwezo as a result of the nature of rains received in that season, farmers placed more emphasis on the occurrence of drought as a production constraint. According to Bothma (2004), rainfall received in many areas of the EC Province is strongly influenced by the relative distance from the sea. Amount and distribution of rainfall received becomes sporadic as distance from the sea increases. The high ranking of occurrence of drought in Mkhwezo was, therefore, expected. This could also explain why farmers in Jixini mentioned occurrence of floods as a constraint, since they are located closer to the sea. Use of varieties with tolerance to biotic and abiotic stresses could help lessen the impacts of unpredictable and extreme weather phenomena.

\section{CONCLUSIONS}

Elderly farmers above 56 years dominated the studied farming communities. The predominant varieties used were local landraces followed by hybrids and improved OPVs. Maize productivity was different across different farming groups. Married farmers and widowed female farmers obtained higher yields when compared with single farmers as they had more resources available to them. The most important constraints, in order of their importance, were too much rain, occurrence of pests and diseases, drought linked to climate change and lack of fencing of the out-fields. Although the study demonstrated a number of constraints affecting maize production, the use of a single variety cannot mitigate against them all. It is recommended that, varieties tolerant to the most common stress factors should be used, and farmers should practice good crop husbandry to minimize the effects of other stress factors. Results from this can be very useful to agricultural extension programs for the improvement of their service delivery in the EC Province of the country. This is because issuing of recommendations to improve productivity will be more effective when there is background knowledge of farmer traits, their varietal use and production constraints.

\section{ACKNOWLEDGEMENT}

We appreciate research funding that was provided by the Govan Mbeki Research and Development Centre at the University of Fort Hare, and the Technology Innovation Agency (PB 111/08) of the Department of Science and Technology in South Africa.

\section{REFERENCES}

ABEBE, G., ASSEFA, T., HARRUN, H., MESFINE, T. AND AL-TAWAHA, A.M. 2005. Participatory Selection of Drought Tolerant Maize Varieties using Mother and Baby. World Journal of Agricultural Sciences 1: 22-27. 
ADESEHINWA, A.O.K., OKUNOLA, J.O. AND ADEWUMI, M.K. 2004. Socio-economic characteristics of ruminant livestock farmers and their production constraints in some parts of South-western Nigeria. Livestock Research for Rural Development 16: 6. Accessed from http://www.lrrd.org/lrrd16/8/ades16061.htm on 12/03/2012.

Agricultural Geo-Referenced Information System (AGIS) 2011. Mapping and GIS software. Accessed from http://www.agismap.com/agisinfo.html on 15/10/2011.

ALAM, G.M. 2010. The role of science and technology education at network age population for sustainable development of Bangladesh through human resource advancement, Scientific Research and Essays 4(11): 1260-1270.

AMAZA, P.S., OLAYEMI, J.K., ADEJOBI, A.O., BILA, Y. AND IHEANACHO, I. 2007. Baseline socioeconomic survey report: agriculture in Borno State, Nigeria. International Institute of Tropical Agriculture, Ibadan, Nigeria. pg 28. Accessed from http://old.iita.org/cms/articlefiles/740-prosab_survey_rpt.pdf on 14/10/2011.

BÄNZIGER, M., SETIMELA, P.S., HODSON, D. AND VIVEK, B. 2005. Breeding for improved abiotic stress tolerance in maize adapted to southern Africa. Agricultural Water Management 80 (1-3): 212-224. Accessed from http://www.sciencedirect.com/science on 10/06/09.

BELLON, M.R. 2001. Participatory Research Methods for Technology Evaluation. A Manual for Scientist Working with Farmers. Mexico, D. F. CIMMYT, pp. 93.

BENNETT, J. 2002. The Role of Arable Land Allocations in Cattle Production Systems in Communal Areas of Central Eastern Cape Province, South Africa. A PhD Thesis, School of Science and the Environment, Coventry University, Coventry.

BOTHMA, J. 2004. Landscape and architectural devices for energy efficient South African suburban residential designs. Msc thesis submitted for examination. University of Pretoria, Pretoria.

BRYNDUM, S., BOYE, C., CHONGTHAM, I.R. AND MONTAGNE, J. 2007. Present and future potentials of agriculture in Pepela Village, Eastern Cape Province, South Africa. Project in interdisciplinary land use and natural resource management. Accessed from http://www.sluse.dk/Courses/ILUNRM/ /media/AGRECO/ on 12/04/2011.

CUMMING, T.L. 2007. Conservation incentives for private commercial farmers in the Thicket biome, Eastern Cape, South Africa. Msc thesis submitted for examination. Rhodes University, Graham's town, South Africa.

DAVIS, J.H.C. AND GARCIA, S. 1982. Competitive ability and growth habit of indeterminate beans and maize foe intercropping. Field crop research 6: $59-75$

DERERA, J., TONGOONA, P., LANGYINTUO, A., LAING, M.D. AND VIVEK, B. 2006. Farmer perceptions on maize cultivars in the marginal eastern belt of Zimbabwe and their implications for breeding. African Journal of Crop Science 14: 1-15.

FANADZO, M., CHIDUZA, C. AND MNKENI, P.N.S. 2009. Comparative response of direct seeded and transplanted maize (Zea mays L.) to nitrogen fertilization at Zanyokwe irrigation scheme, Eastern Cape, South Africa. African Journal for Agriculture 4 (8): 689-694.

FANADZO, M., CHIDUZA, C., MNKENI, P.N.S., VAN DER STOEP, I. AND STEVENS, J. 2010. Crop production management practices as a cause for low water productivity at Zanyokwe irrigation Scheme. Water SA (Online) 32:1, Pretoria Accessed from http://www.scielo.org.za/scielo.php?pid=S1816-79502010000100004\&script on 06/08/2010.

FISCHER, K, VAN DEN BERG, J. AND MUTENGWA, C. 2015. Is Bt maize effective in improving South African smallholder agriculture? South African Journal of Science, 111(1/2), Art. \#a0092, 2 pages. http://dx.doi.org/10.17159/sajs.2015/a0092. 
HEONG, K.L., ESCALADA, M.M., SENGSOULIVONG, J. AND SCHILLER, J. 2002. Insect management beliefs and practices of rice farmers in Laos. Agriculture Ecosystems and Environments 92: 137-145.

ISREAL, S.H., MZILENI, N.T., PEARSON, R.A. AND O’NEILL, D.H. 1999. Seasonal contributions of draught animals to activities in small-scale "emerging" farmers in the Eastern cape of South Africa. Centre for Tropical Veterinary Medicine, Draught Animal Power Technical Report 2. Accessed from http://www.dfid.gov.uk/r4d/PDF/Outputs/R6609g.pdf on 18/07/2011.

JACOBSON, K, 2013. From betterment to Bt maize. Agricultural development and the introduction of genetically modified maize to South African smallholders. Doctoral Thesis No. 2013:28. Faculty of Natural resources and Agricultural Sciences. Sweedish University of Agricultural Sciences, Uppsala.

KARIMURIBO, E.D., CHENYAMBUGA, S.W., MAKENE, V.W. AND MATHIAS, S. 2011. Characteristics and production constraints of rural-based small-scale pig farming in Iringa region, Tanzania. Livestock Research for Rural Development 23, 172. Accessed from http://www.lrrd.org/lrrd23/8/Kari23172.htm on 12/04/2012.

KEPE, T. AND TESSARO, D. 2013. Trading-off: Rural food security and land rights in South Africa. Land Use Policy 36 (2014): 267-274. doi: 10.1016/j.landusepol.3013.08.013

KHAPAYI, M. AND CELLIERS, P.R. 2016. Factors limiting and preventing emerging farmers to progress to commercial agricultural farming in the King William's town area of the Eastern Cape Province, South Africa. S. Afr. J. Agric. Ext. 44(1): 25-41. doi: 10.17159/2413-3221/2016/v44n1a374.

KOTEY, D.A., ASSEFA, Y. AND VAN DEN BERG, J. 2017. Enhancing smallholder farmers' awareness of GM maize technology, management practices and compliance to stewardship requirements in the Easter Cape Province of South Africa: the role of public extension and advisory services. South African Journal of Agricultural Extension 45(2): 49-63. doi: 10.17159/2413-3221/2017/v45n2a433.

MANDIRINGANA, O.T., MNKENI, P.N.S., MKILE, Z., VAN AVERBEKE, W., VAN RANST, E. AND VERPLANCKE, H. 2005. Mineralogy and fertility status of selected soils of the Eastern Cape Province, South Africa. Soil Science and Plant Analysis. 36: 2431-2446.

MANYEVERE, A., MUCHAONYERWA, P., LAKER, M.C. AND MNKENI, P.N.S. 2014. Farmers' perspectives with regard to crop production: an analysis of Nkonkobe Municipality, South Africa. Journal of Agriculture and Rural Development in the Tropics and Subtropics 115 (1): 41-53. ISSN: 1612-9830.

Masifunde Education \& Development Trust Program (MEDTP) 2010. Threats to the food security and sovereignty in the Eastern Cape. Impacts of the Massive Food Production Programme (MFPP), GMOs and cash crops in four villages in the Amatole District Municipality. Published by Masifunde education and Development trust program. Accessed from http://www.biosafety-info.net/file_dir/9260820094dda3a605ad33.pdf. on $01 / 07 / 2011$.

MAPIYE, C., CHIMONYO, M., DZAMA, K., RAATS, J.G. AND MAPEKULA, M. 2009. Opportunities for improving Nguni cattle production in the smallholder farming systems of South Africa. Livestock science 65, 124, 196-204.

MATATA, P.Z., AJAYIL, O.C., ODUOL, P.A. AND AGUMYA, A. 2008. Socio-economic factors influencing adoption of improved fallow practices among smallholder farmers in western Tanzania. International NGO Journal 3(4), 68-73. 
MATIWANA, Z. 2011. The ugly truth about GM crops in the Eastern Cape. (unpublished) Accessed from http://www.ru.ac.za/modules/blog_include/blog_content.php?=1973 on $01 / 07 / 2011$.

MBUTI, M.C. 2000. Crop production systems. In: E. Van Ranst, H. Verplancke, W. Van Averbeke, A. Verdoodt \& J. Bonroy (eds). Rural livelihoods in the central Eastern Cape, South Africa. Extended abstracts of an International Workshop, 20-22 June 2000, Ghent, Belgium. The Laboratory of Soil Science, University of Gent, pp36-38.

MC CAIN, C. 2000. Maize and Grace: history, Corn and Africas' new landscapes; 1500-1999. Accessed

from www.ruafrica.rutgers.edu/events/media/0.405_media/maize_and_grace $16 / 05 / 2011$.

MC CAIN, M. 2005. Annexure 2: District Profile Eastern Cape Tambo District Municipality (DC15). Programme of Support to Local Economic Development in the Eastern Cape. Eastern Cape Competitive Advantage Assessment and Training Support Project. European Consultants Organisation (ECO). Accessed from http://www.thinasinako.co.za/files/documents/290806175904.pdf. on 06/08/2011.

MNQAWA, P., MANGENA-NETSHIKWETA, M.L. AND KATERERE, D.R. 2016. Grain production by rural subsistence farmers in selected districts of Limpopo and Mpumalanga provinces South Africa. PULA: Botswana Journal of African Studies 30(1): 49-63.

MUSEMWA, L., MUSHUNJE, A., CHIMONYO, M., FRASER, G., MAPIYE, C. AND MUCHENJE, V. 2008. Nguni cattle marketing constraints and opportunities in the communal areas of South Africa: Review. African Journal of Agricultural Research 3 (4): 239-245.

MUSVOSVI, C. 2009. Morphological characterization and interrelationships among descriptors in some cowpea genotype. African Crop Science Conference proceedings 9: 501-507.

NCUBE, B.L. 2017. Institutional support systems for small-scale farmers at new forest irrigation scheme in Mpumalanga, South Africa: constraints and opportunities. South African Journal of Agricultural Extension 45(2): 1-13. doi: 10.17159/24133221/2017/v45n2a395.

NDIYO, D. AND URASSA, J.K. 2002. Gender imbalance in agricultural and non-agricultural activities and its impact on household food security: A case study of Morogoro rural. Electronic Publications from Sokoine University of Agriculture, Morogoro, Tanzania. Accessed from http://www.fiuc.org/iaup/sap/pdf. on 25/06/2010.

NTARE, B.R., NDJEUNGA, J., WALIYAR, F., KODIO, O., ECHEKWU, C.A., KAPRAN, I., DA SYlVA, A., DIALlO, A.T., AMADOU, A., BISSALA, H.Y. AND SAKO, K. 2007. Farmer Participatory Evaluation and Dissemination of Improved Groundnut Varieties in West Africa. International Crops Research Institute for the Semi-Arid Tropics. 36 pp.

ODENDO, M., DE GROOTE, H. AND ODONGO, O.M. 2002. Assessment of Farmers' Preferences and Constraints to Maize Production in the Moist Mid-Altitude Zone of Western Kenya. In Proceedings of the 5th International Conference of the African Crop Science Society, edited by African Crop Science Association. Lagos, Nigeria: African Crop Science Association. Pp. 769-775.

ODOEMENEM, I.U. AND ADEBISI, V. 2011. Sustainable agriculture for small scale farmers in Niger state, Nigeria Journal of Sustainable Development in Africa 13(2): 56 - 65 
OKOYE, B.C., ONYENWEAKU, C.E., UKOHA, O.O., ASUMUGHA, G.N. AND ANIEDU, O.C. 2008. Determinants of labour productivity on small-holder cocoyam farms in Anambra State, Nigeria. Scientific Research and Essay 3: 559-561.

PAUW, K. 2006. A profile of the Eastern Cape Province South Africa: Demographic Poverty, Inequality and Unemployment. PROVIDE Project Background paper (2005):1(2) Accessed from www.elsenburg.com/economic/PROVIDE on 03/09/09.

PIXLEY, K. AND BÄNZIGER, M. 2001. Open pollinated maize varieties: A backward step or valuable option for farmers. Seventh Eastern and Southern Africa Regional Maize Conference 11th-15th February, 2001. pp. 22-28

PROVIDE 2009. A profile of East Cape Province: Demography, poverty, income, inequality and unemployment from 2000 till 2007. Project background paper, 2009. Accessed from

http://www.elsenburg.com/provide/reports/background/BP2009_1_2_EChics.pdf. on 23/06/2011.

RABIEE, F. 2004. Focus group interview and data analysis. Proceedings of Nutrition Society. 63(4), 655-660.

ROSENZWEIG, C., INGLESIAS, A., YANG, X.B., EPSTEN, P.R. AND CHIVAN, E. 2000. Climate change and U.S. Agriculture. The impact of warming and extreme weather events on productivity, plant diseases and pests. Published by, Centre for health and Global Environment. Harvard Medical School, Boston.

S.A.S. 2010. JMP® Statistical Discovery Software. http://www.jmp.com/software

SIBANDA, M. 2012. Assessment of Keiskammahoek, Zanyokwe Irrigation Scheme and OR Tambo district municipality on livelihoods, market size and potential adoption of open pollinated varieties (OPVs) of maize in the Eastern Cape. Msc thesis submitted for examination. University of Fort Hare, Alice.

TANDZI, N.L., NGONKEU, M.E., NARTEY, E., YEBOAH, M., NGEVE, J., MAFOUASSON, H.A., NSO NGANG, A BASSI, O. AND GRACEN, V. 2015. Farmers' adoption of improved maize varieties in the humid forest area of Cameroon. International Journal of Scientific Engineering and Applied Science 1(8): 17-28. ISSN: 2395-3470.

Water Service Report Tool 2001. Accessed from http://www.dwaf.gov.za/dir_ws/WaterServices/reports/pg_reports.asp? on 12/09/2011. 
S. Afr. J. Agric. Ext.

Chimonyo, Mutengwa, Chiduza \& Tandzi

Vol. 48 No.2, 2020: 64 - 82

http://dx.doi.org/10.17159/2413-3221/2020/v48n2a538

(License: CC BY 4.0) 